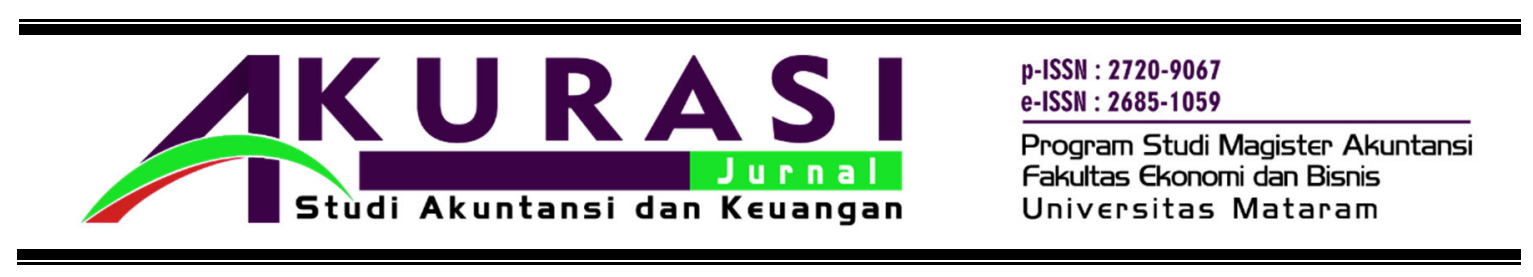

\title{
PENGARUH PENGGUNAAN SIMDA TERHADAP KUALITAS LAPORAN KEUANGAN DAN DAMPAKNYA TERHADAP PENCEGAHAN FRAUD PENGELOLAAN BARANG MILIK DAERAH
}

\author{
Handia Fahrurrozi ${ }^{1}$ \\ Badan Pengelola Keuangan dan Aset Daerah (BPKAD) Provinsi Nusa Tenggara Barat \\ email: handia.imali@gmail.com
}

\begin{tabular}{|c|c|}
\hline INFORMASI ARTIKEL & ABSTRAK \\
\hline $\begin{array}{l}\text { Article history: } \\
\text { Dikirim : } 21 \text { Agustus } 2019 \\
\text { Revisi pertama : } 9 \text { Desember } 2019 \\
\text { Diterima: 11 Desember } 2019 \\
\text { Tersedia online : } 15 \text { Desember } 2019\end{array}$ & $\begin{array}{l}\text { Penyelenggaraan pemerintahan harus berorientasi pada maksimalisasi } \\
\text { pelayanan dengan hasil yang dapat dipertanggungjawabkan dan } \\
\text { meminimalisir terjadinya penyalahgunaan fasilitas publik. Penelitian ini } \\
\text { bertujuan untuk menguji pengaruh penggunaan Sistem Informasi } \\
\text { Manajemen Barang Milik Daerah (SIMDA) terhadap kualitas laporan } \\
\text { keuangan pemerintah daerah dan dampaknya terhadap pencegahan fraud } \\
\text { pengelolaan barang milik daerah. Populasi penelitian adalah } 128 \text { pengurus } \\
\text { barang dan ASN Bidang Pengelolaan BMD. Seleksi sampel sebanyak } 80 \\
\text { responden menggunakan purposive sampling. Analisis data menggunakan } \\
\text { model persamaan struktural. Hasil Penelitian menunjukkan bahwa } \\
\text { penggunaan SIMDA tidak berpengaruh terhadap kualitas laporan } \\
\text { keuangan dan pencegahan fraud pengelolaan barang milik daerah. } \\
\text { Kualitas laporan keuangan juga tidak berdampak signifikan dalam } \\
\text { pencegahan fraud dalam pengelolaan barang milik daerah. Hasil penelitian } \\
\text { ini memberikan implikasi praktis tentang pentingnya optimalisasi } \\
\text { pemanfaatan SIMDA dalam menyediakan informasi yang dapat } \\
\text { diandalkan dan relevan terutama dalam pengambilan keputusan pada } \\
\text { organisasi pemerintahan daerah. } \\
\text { Kata kunci: SIMDA, Laporan Keuangan, Pencegahan Fraud Pengelolaan } \\
\text { Barang Milik Daerah }\end{array}$ \\
\hline
\end{tabular}

\begin{abstract}
The government administration must be oriented towards maximizing services with accountable results and minimizing the misuse of public facilities. This study aims to examine the effect of using Management Information System for Local Government's Goods (SIMDA) on the quality of local government financial reports and their impact on fraud prevention in the management of regional property. The research population was 128 goods administrator and government civil servants in the regional government's property management sector. The sample selection of 80 respondents using purposive sampling.The data of this study were analyzed using structural equation modeling. The research findings showed that the use of SIMDA had no effect on the quality of financial statements and fraud prevention in the management of regional property. The quality of financial statements also does not have a significant impact in preventing fraud in the management of regional property. The result of this study result provide practical implications about importance of optimizing the use of SIMDA in providing reliable and relevant information, particularly related to the decision making of local government organization.

Keywords: SIMDA,Financial statements, Fraud Prevention of local government Asset
\end{abstract}




\section{Pendahuluan}

Penyelenggaraan Pemerintahan bertujuan untuk menyejahterakan masyarakat, sebagaimana yang tercantum dalam amanat Pembukaan Undang Undang Dasar 1945. Pemerintah sebagai salah satu organisasi sektor publik dituntut agar dapat melakukan pelayanan secara efektif dan efisien. Tata kelola pemerintahan merupakan salah satu cerminan dari kualitas pelayanan pemerintah. Masyarakat dewasa ini menuntut agar organisasi pemerintah memiliki tata kelola yang baik atau good government governance. Peran tata kelola sendiri sejatinya lebih luas daripada sekadar efisiensi dan penggunaan sumber daya yang ekonomis. Namun, good governance merupakan strategi untuk menciptakan institusi masyarakat yang kuat, dan juga untuk membuat pemerintahan semakin terbuka, responsif, akuntabel dan demokratis (Warsito, 2014).

Good government governance dapat dikembangkan menjadi modern government yang dapat bertujuan untuk mencegah fraud yang berupa penyalahgunaan fasilitas publik untuk kepentingan pribadi melalui karakteristik yang dimiliki oleh good governance yang terdiri atas : transparan, akuntabel, adil, wajar, demokratif, partisipatif dan responsif. Dari ketujuh karakteristik yang dimiliki oleh good government yang paling dominan menjadi perhatian masyarakat adalah masalah akuntabel atau pertanggungjawaban. Pemerintah sebagai institusi yang memungut serta mengelola dana dari masyarakat berkewajiban untuk mempertanggungjawabkan dana yang dikelolanya secara periodik. Laporan Keuangan Pemerintah Daerah (LKPD) merupakan salah satu bentuk akuntabilitas pemerintah daerah. Laporan Keuangan Pemerintah Daerah tersebut harus disusun berdasarkan standar yang telah ditetapkan serta berkualitas baik itu dari sisi relevansi dan keandalannya.

Karakteristik laporan keuangan terdiri atas relevansi, keandalan, dapat dibandingkan dan dapat dipahami. Laporan Keuangan Pemerintah Daerah harus mampu disajikan dengan relevan artinya bahwa Pemerintah Daerah harus mampu menyajikan data terkini atas pertanggungjawaban keuangan yang telah diselenggarakan. Penggunaan SIMDA sebagai sistem informasi yang digunakan telah dapat membantu Pemerintah Daerah dalam menyajikan laporan secara relevan. Kondisi ini sejalan dengan fenomena yang terjadi pada Pemerintah Provinsi Nusa Tenggara Barat dimana setelah menggunakan SIMDA, opini atas Laporan Keuangan Pemerintah Daerah (LKPD) meningkat drastis dari sebelum penggunaan SIMDA adalah opini terendah yakni disclaimer menjadi Wajar Tanpa Pengecualian (WTP) setelah menggunakan SIMDA. Penggunaan SIMDA sebagai alat yang digunakan oleh Pemerintah dalam menyusun Laporan Keuangan Pemerintah Daerah telah berlangsung secara masif. Berdasarkan data dari laman www.bpkp.go.id pada tahun 2015 terdapat 78,41\% Pemerintah Daerah telah menggunakan SIMDA. Hal ini mengkonfirmasi hasil penelitian yang dilakukan oleh Laksono (2017) bahwa kualitas informasi yang dihasilkan oleh penggunaan SIMDA berpengaruh terhadap Laporan Keuangan Pemerintah Daerah. Temuan tersebut juga sejalan dengan penelitian Pulungan (2014) yang menguji tentang optimalisasi SIMDA dalam mewujudkan pengelolaan keuangan. Hasilnya menyatakan bahwa penggunaan SIMDA secara optimal dapat 
menghasilkan laporan keuangan yang berkualitas baik dari sisi relevansi maupun keandalannya.

Meskipun beberapa hasil penelitian mendukung kebermanfaatan penggunaan SIMDA dalam menghasilkan laporan keuangan yang berkualitas, namun dalam kenyataannya tidak berbanding lurus dengan beberapa fenomena yang terjadi dalam pengelolaan keuangan pemerintah daerah, terutama yang berkaitan dengan manajemen aset pemerintah daerah. Sebagai contoh, Pemerintah Provinsi Nusa Tenggara Barat (NTB) walaupun semenjak tahun 2012 memperoleh opini wajar tanpa pengecualian dari Badan Pemeriksa Keuangan (BPK), namun masih memiliki beberapa catatan terkait dengan pengelolaan barang milik daerah yang tak kunjung selesai dalam kurun waktu beberapa tahun. Pertama, temuan Inspektorat Provinsi NTB terkait aset mangkrak yang tidak dimanfaatkan dalam upaya meningkatkan produktivitas pemerintah (www.suarantb.com). Kedua, temuan Badan Pemeriksa Keuangan tahun 2017 terhadap aset daerah senilai 1,4 miliar pada mantan anggota dewan dan pimpinan DPRD (http://lombokpost.net). Ketiga, Laporan Hasil Pemeriksaan (LHP) BPK tahun 2018 yang mengindikasikan adanya potensi kerugian negara pada 7 temuan yang termuat dalam LHP tersebut mencapai nilai 7,7 miliar rupiah. Fenomena ini tentunya menjadi tantangan yang cukup berat untuk dapat mewujudkan modern government yang memiliki tujuan untuk mencegah terjadinya fraud berupa penyalahgunaan fasilitas publik. Fenomena ini juga dikonfirmasi oleh penelitian yang dilakukan oleh Fahrurrozi, Akram dan Basuki (2019) yang menguji peran SIMDA Barang Milik Daerah (SIMDA BMD) baik secara langsung maupun tidak langsung terhadap penceghan fraud pengelolaan barang milik daerah. Hasil penelitiannya menunjukkan bahwa SIMDA BMD tidak berpengaruh terhadap pencegahan fraud pengelolaan barang milik daerah.

Adanya research gap dan beberapa fenomena yang terjadi inilah yang melatarbelakangi pengujian pengaruh SIMDA terhadap laporan keuangan serta dampaknya terhadap pencegahan fraud pengelolaan barang milik daerah. Hal ini didasarkan pada peran SIMDA sebagai salah satu alat pengendalian dari Sistem Pengendalian Internal yang dimiliki oleh Pemerintah Daerah, serta didasarkan pada argumentasi Pentagon Fraud Theory bahwa tindakan fraud dapat disebabkan oleh empat motif antara lain tekanan, kesempatan, rasionalitas, kapabilitas. Penggunaan SIMDA yang cenderung mempersempit kesempatan penyalahgunaan fasilitas publik harusnya dapat memperkuat pencegahan fraud dalam pengelolaan barang milik daerah. Namun, faktor kontekstual dalam fenomena yang berbeda memungkinkan dampak yang berbeda.

Penelitian ini memiliki beberapa kebaruan jika dibandingkan dengan penelitian Fahrurrozi dkk (2019). Pertama, pengujian penelitian ini dilaksanakan dengan menguji pengaruh langsung SIMDA terhadap kualitas laporan keuangan pemerintah daerah, setelah itu baru menganalisis dampaknya terhadap pencegahan fraud barang milik daerah. Kedua, penelitian ini menempatkan peran SIMDA sebagai objek utama pengujian untuk dianalisis pengaruhnya terhadap pencegahan fraud barang milik daerah, sementara dalam penelitian sebelumnya (Fahrurrozi dkk, 2019) menguji SIMDA sebagai variabel intervening. Dengan demikian, penelitian ini bertujuan untuk menguji pengaruh SIMDA terhadap Laporan Keuangan Pemerintah Daerah (LKPD) serta dampaknya terhadap pencegahan fraud dalam pengelolaan barang milik daerah. Hasil penelitian ini dapat memberikan kontribusi untuk 
mengoptimalkan peran penting dari SIMDA sebagai sistem informasi daerah dalam mendukung tercapainya kualitas laporan keuangan yang andal dan relevan dalam penentuan kebijakan dan pengambilan keputusan pada pemerintah daerah.

\section{Kerangka Teoretis Dan Pengembangan Hipotesis}

Penyelenggaran pemerintahan bertujuan untuk menyejahterakan masyarakatnya. Dewasa ini tata kelola pemerintah menjadi indikator bagaimana kemampuan pemerintah dalam mengelola amanah yang diberikan. Ciri utama dari tata kelola pemerintah yang baik adalah adanya akuntabilitas yang ditunjukkan dengan Laporan Keuangan Pemerintah Daerah yang berkualitas. Laporan keuangan yang berkualitas setidaknya memilik empat karakteristik yakni relevan, andal, dapat dipahami dan dapat dibandingkan. Laporan yang berkualitas tersebut juga dalam perspektif modern government harus dapat meminimalisir kecurangan yang berupa penyalahgunaan fasilitas publik.

Menurut Mariam-Webster dictionary "fraud is deceit or trickery specifically: intentional perversion of truth in order to induce another to part with something of value or to surrender a legal right". Terdapat beberapa teori tentang motivasi pelaku melakukan tindakan fraud antara lain yang dikemukan oleh Cressey (1950) yang terdiri atas : tekanan, kesempatan dan rasionalisasi. Menurut Puspasari (2016) kesempatan merupakan elemen yang paling memungkinkan untuk memperkecil terjadinya fraud melalui proses, prosedur, pengendalian dan deteksi dini dalam usaha melawan fraud. Teori lain dikemukan oleh Albercht, Howe dan Romney (1984) yang disebut dengan fraud scale yang terdiri dari tiga faktor penyebab fraud yakni: situasional pressure, opportunity to commit fraud, and personal integrity. Pada dasarnya teori yang dimukakan oleh Cressey dan Albercht adalah sama, namun Albercht menggunakan personal integrity untuk mengganti rasionalisasi karena lebih mudah untuk lakukan observasi.

Selain itu, Bologna (1993) juga mengemukakan teori fraud yang lazim disebut Gone theory. Gone merupakan akronim dari motivasi pelaku melakukan tindakan fraud yang terdiri atas greed, opportunity, need, exposure. Greed dan need merupakan faktor yang berhubungan dengan individu pelaku fraud atau faktor individual. Sementara opportunity_dan exposure merupakan faktor yang berhubungan dengan organisasi sebagai korban perbuatan fraud, atau disebut dengan faktor genetik (BPKP, 2008). Perkembangan teori fraud dikemukan oleh Dorminey dkk (2012) dimana motivasi pelaku melakukan tindakan fraud dibagi menjadi empat yakni tekanan, kesempatan, rasionalisasi dan kapabilitas.

Berkaitan dengan laporan keuangan keuangan pemerintah daerah, laporan keuangan merupakan salah satu bentuk pertanggungjawaban dari pengelolaan daerah yang dilakukan oleh Pemerintah. Menurut PP 08 tahun 2006 menyatakan bahwa laporan keuangan merupakan bentuk pertanggungjawaban pengelolaan keuangan negara/daerah selama suatu periode. Berdasarkan PP 71 tahun 2010 tentang Standar Akuntansi Pemerintah (SAP) laporan keuangan pemerintah daerah terdiri atas: Laporan Keuangan (LK), Laporan Operasional (LO), Laporan Arus Kas (LAK), Laporan Perubahan Saldo Anggaran Lebih (L-SAL), Laporan Perubahan Ekuitas (LPE) dan Catatan atas Laporan Keuangan (CaLK). Laporan Keuangan Pemerintah Daerah terdiri atas tiga komponen utama yakni: Aset, Kewajiban dan Ekuitas. Barang milik daerah merupakan salah satu 
komponen aset yang memegang porsi terbesar dalam laporan keuangan. Oleh karena itu, pengendalian terhadap barang milik daerah dari tindakan fraud menjadi sangat penting dengan salah satu caranya adalah memastikan bahwa laporan keuangan yang disajikan berkualitas.

Karakteristik kualitatif laporan keuangan adalah ukuran-ukuran normatif yang perlu diwujudkan dalam informasi akuntansi sehingga dapat memenuhi tujuannya. Keempat karakteristik berikut ini merupakan prasyarat normatif yang diperlukan agar laporan keuangan pemerintah dapat memenuhi kualitas yang dikehendaki yakni: relevan, andal, dapat dipahami dna dapat dibandingkan (PP 71 tahun 2010). Karakteristik laporan keuangan yang pertama yakni relevan, laporan keuangan dikatakan relevan apabila informasi yang termuat di dalamnya dapat mempengaruhi keputusan pengguna dengan membantu mereka mengevaluasi peristiwa masa lalu atau masa kini, dan memprediksi masa depan, serta menegaskan atau mengoreksi hasil evaluasi mereka di masa lalu. Dengan demikian, informasi laporan keuangan yang relevan dapat dihubungkan dengan maksud penggunaannya (PP 71 tahun 2010). Informasi yang relevan memuat beberapa unsur yakni memiliki manfaat umpan balik, memiliki manfaat prediktif, tepat waktu dan lengkap. Karakteristik laporan keuangan yang andal, berarti bahwa informasi dalam laporan keuangan bebas dari pengertian yang menyesatkan dan kesalahan material, menyajikan setiap fakta secara jujur, serta dapat diverifikasi. Informasi mungkin relevan, tetapi jika hakikat atau penyajiannya tidak dapat diandalkan maka penggunaan informasi tersebut secara potensial dapat menyesatkan. Informasi yang andal memenuhi karakteristik antara lain: penyajian jujur, dapat diverifikasi dan netralitas. Karakteristik ketiga yakni dapat dibandingkan, informasi yang termuat dalam laporan keuangan akan lebih berguna jika dapat dibandingkan dengan laporan keuangan periode sebelumnya atau laporan keuangan entitas pelaporan lain pada umumnya (PP 71 tahun 2010). Karakteristik kualitas laporan keuangan adalah laporan yang dihasilkan harus dapat dipahami, artinya informasi yang disajikan dalam laporan keuangan dapat dipahami oleh pengguna dan dinyatakan dalam bentuk serta istilah yang disesuaikan dengan batas pemahaman para pengguna. Pengguna diasumsikan memiliki pengetahuan yang memadai atas kegiatan dan lingkungan operasi entitas pelaporan, serta adanya kemauan pengguna untuk mempelajari informasi yang dimaksud (PP 71 tahun 2010).

Sistem Informasi Keuangan Daerah (SIKD) merupakan sistem yang mendokumentasikan, mengadministrasikan, serta mengolah data pengelolaan keuangan daerah dan data terkait masyarakat dan sebagai bahan pengambilan keputusan dalam rangka, perencanaan, pelaksanaan, dan pelaporan pertanggungjawaban pemerintah daerah (PP 56 tahun 2005). SIKD merupakan payung hukum dalam implementasi pengelolaan keuangan daerah menggunakan Sistem Informasi Manajemen Keuangan dan Aset Daerah atau lazim disebut dengan SIMDA yang dikembangkan oleh Satuan Tugas SIMDA BPKP. Pengembangan aplikasi SIMDA oleh BPKP terbagi menjadi dua aplikasi utama yakni SIMDA Keuangan untuk pelaporan keuangan dan SIMDA Barang Milik Daerah (SIMDA BMD) untuk pelaporan barang milik daerah yang didukung dengan beberapa aplikasi lainnya yakni: SIMDA Gaji, SIMDA Pendapatan, Sub Aplikasi Display SPP sampai dengan SP2D, Sub Aplikasi Gabungan per Provinsi dan Sub Aplikasi Rekonsiliasi Bank. 


\section{Pengembangan Hipotesis}

Sistem Informasi Manajemen Keuangan dan Aset Daerah (SIMDA BMD), merupakan instrumen yang digunakan oleh Pemerintah Daerah untuk menyusun Laporan Keuangan Pemerintah Daerah (LKPD). Laporan keuangan yang disusun menggunakan SIMDA dapat meningkatkan kualitas laporan keuangan yang disusun karena memenuhi unsur karakteristik laporan keuangan. Dari unsur relevansi, laporan yang disusun menggunakan SIMDA dapat diaskses secara realtime, dari sisi keandalan aplikasi yang dikembangkan oleh Satgas SIMDA BPKP memiliki reputasi yang baik sebagaimana dikemukakan dalam penelitian yang dilakukan oleh Supriyanto (2015). Penggunaan SIMDA diharapkan mampu mencegah terjadinya penyalahgunaan fasilitas publik sehingga SIMDA akan menunjang tercapainya laporan keuangan pemerintah dearah yang berkualitas. Berdasarkan argumentasi tersebut maka diajukan hipotesis sebagai berikut:

$\mathrm{H}_{1}$ : Penggunaan SIMDA berpengaruh terhadap kualitas Laporan Keuangan Pemerintah Daerah

Studi Al-Hiyari (2013) menguji faktor-daktor yang mempengaruhi penerapan sistem informasi akuntansi dan dampaknya terhadap kualitas informasi akuntansi. Hasil penelitiannya menemukan bahwa komitmen manajemen, kualitas data dan sistem informasi berpengaruh signifikan. Namun demikian, sumber daya manusia tidak berpengaruh terhadap penerapan sistem informasi dan kualitas informasi akuntansi. Hasil penelitian ini didukung oleh penelitian Rapina (2014) serta penelitian Fitriani dan Mulyani (2015) bahwa komitmen manajemen merupakan faktor yang dapat mempengaruhi kualitas sistem informasi. Ketika kualitas laporan keuangan yang meningkat dapat mencegah terjadinya potensi kecurangan sehingga dapat dirumuskan hipotesis sebagai berikut :

$\mathrm{H}_{2}$ : Kualitas Laporan Keuangan Pemerintah Daerah berpengaruh terhadap pencegahan Fraud Pengelolaan Barang Milik Daerah

Hasil penelitian Maksum, Subekti dan Baridwan (2017) menguji faktor yang mempengaruhi keberterimaan penggunaan SIMDA pada Pemerintah Kota Batu dengan model penelitian Technology Acceptance Model (TAM). Hasil penelitiannya menunjukkan bahwa keberterimaan SIMDA dipengaruhi oleh kegunaan persepsian dan kemudaan penggunaan persepsian. Efektifitas penggunaan SIMDA ini tentunya dapat dikonfirmasi juga dengan jumlah pengguna SIMDA oleh Pemerintah Daerah seluruh Indonesia yang telah mencapai $78,41 \%$. Sementara itu, dalam penelitian yang dilakukan oleh Al-Zwyalif (2015) membagi pengendalian intern menjadi 3 unsur yaitu pencegahan, pendeteksian dan koreksi. Sementara dari sisi segmennya dibagi menjadi dua yakni general control dan application control. Salah satu bentuk dari application control adalah penggunaan SIMDA. Alfian (2015) menyatakan bahwa sistem informasi yang baik dapat digunakan menjadi nilai tambah suatu organisasi dan dapat digunakan sebagai alat kontrol. Dalam penelitian yang sama Alfian (2015) juga menemukan bahwa implementasi SIMDA dapat berpengaruh terhadap kualitas laporan keuangan. Dengan demikian diajukan hipotesis sebagai berikut :

$\mathrm{H}_{3}$ : Penggunaan SIMDA BMD berpengaruh terhadap pencegahan Fraud Pengelolaan Barang Milik Daerah 


\section{Metode Penelitian}

Penelitian ini dilakukan pada Organisasi Perangkat Daerah (OPD) pada Pemerintah Provinsi Nusa Tenggara Barat. Populasi penelitian merupakan pengurus barang dan pengurus barang pembantu pada OPD serta Aparatur Sipil Negara (ASN) Bidang Pengelolaan BMD pada Badan Pengelolaan Keuangan dan Aset Daerah (BPKAD). Populasi penelitian berjumlah 128 orang yang terdiri dari 115 orang pengurus barang dan 13 orang ASN Bidang Pengelolaan BMD. Pengambilan sampel penelitian menggunakan teknik non probability sampling yakni purposive sampling. Kriteria sampel yang digunakan adlh sebagai berikut: (1) Pengurus Barang/Pengurus Barang Pembantu OPD/UPTD/B; (2) Bidang Pengelolaan BMD pada Pejabat Penatausahaan Barang Milik Daerah; (3) OPD/UPTD/B yang berada di wilayah Pulau Lombok dan (4) OPD/UPTD/B yang memiliki nilai total aset per 31 Desember 2017 lebih besar dari 5 miliar.

Data penelitian dikumpulkan menggunakan kuesioner, sementara teknik analisis data dilaksanakan setelah data terkumpul dari responden. Terdapat dua macam statistik yang digunakan untuk analisis data dalam penelitian, yaitu statistic descriptive, dan statistic inferensial (Sugiyono, 2014:147). Statistik deskriptif adalah statistik yang digunakan untuk menganalisis data dengan cara mendeskripsikan atau menggambarkan data yang telah terkumpul sebagaimana adanya tanpa bermaksud membuat kesimpulan yang berlaku umum atau generalisasi. Analisis data menggunakan statistik inferensial dibagi menjadi dua jenis sesuai dengan jenis data yang diolah yakni statistik parametrik dan nonparametrik. Menurut Sugiyono (2014:149) statistik parametrik digunakan untuk menguji parameter populasi melalui statistik, atau menguji ukuran populasi melalui data sampel. Pengujian data dalam penelitian ini menggunakan metode Partial Laeast Squares dengan aplikasi SmartPLS 3.2.6.

Variabel penelitian ini melibatkan variabel eksogen dan endogen yang direfleksikan dengan indikator-indikator. Variabel eksogen terdiri dari efektivitas penggunaan SIMDA, sedangkan variabel endogen terdiri dari kualitas laporan keuangan dan pencegahan fraud Barang Milik Daerah (BMD). Variabel eksogen efektivitas penggunaan SIMDA merupakan kualitas sistem yang diukur dengan fleksibilitas sistem, integritas sistem, perbaikan kesalahan dan kenyamanan akses. Variabel endogen kualitas laporan keuangan merupakan diukur dengan indikator relevansi, keandalan, dapat dipahami dan dapat dibandingkan merujuk pada PP 71 tahun 2010. Adapun variabel endogen pencegahan fraud pengelolaan Barang Milik Daerah diukur dengan kejujuran dan etika, evaluasi dan proses pengendalian strategi anti fraud serta mengembangkan proses pengawasan merujuk pada Statement of Auditing Standard 99 (SAS 99).

Metode analisis PLS ini merupakan metode analisis yang powerful dan sering disebut sebagai soft modeling karena meniadakan asumsi-asumsi OLS (Ordinary Least Squares) regresi, seperti data harus terdistribusi normal secara multivariate dan tidak adanya problem multikolineritas antar variabel eksogen (Wold (1985) dalam Ghozali dan Latan, 2015:5). Tahapan analisis menggunakan SmartPLS melalui 5 (lima) tahapan yaitu: (1) konseptualisasi model, (2) menentukan metode analisis algorithm, (3) menentukan metode resampling, (4) menggambar diagram jalur, dan (5) evaluasi model. Konseptualisasi model terdiri atas model pengukuran (outer model) dan model struktural 
(inner model). Diagram jalur disajikan pada gambar 1 dan persamaan model struktural penelitian yang diuji adalah sebagai berikut.

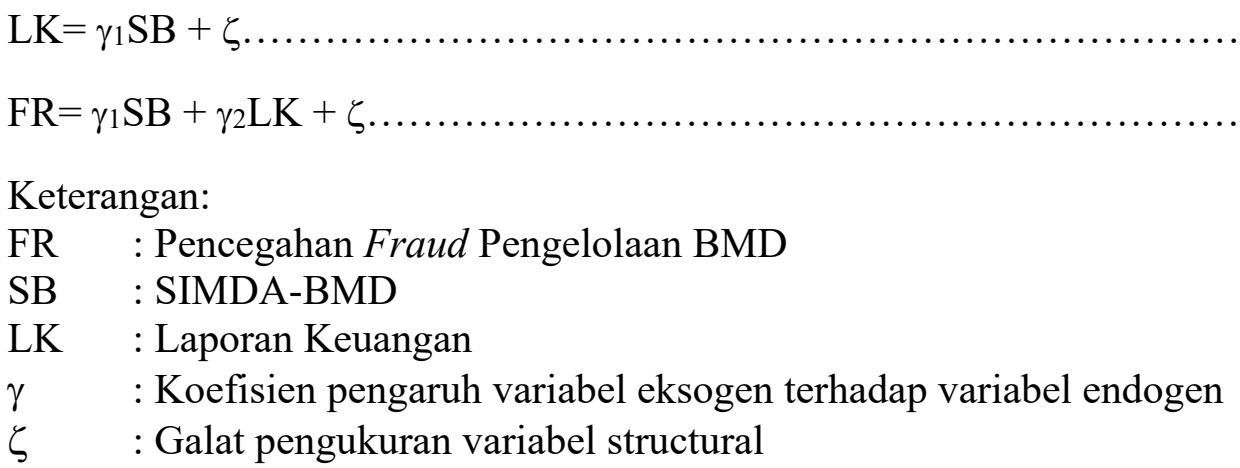

Keterangan:

FR : Pencegahan Fraud Pengelolaan BMD

SB : SIMDA-BMD

LK : Laporan Keuangan

$\zeta \quad$ : Galat pengukuran variabel structural

\section{Hasil dan Pembahasan}

Evaluasi model pengukuran (outer model) dilakukan untuk menilai validitas dan reliabilitas model. Outer model dengan indikator refleksif dievaluasi melalui validitas convergent dan validitas discriminant dari indikator pembentuk kontruk laten dan composite reliability serta cronbach's alpha untuk blok indikatornya. Uji validitas convergent indikator reflektif dapat disajikan pada tabel 1 dengan nilai loading factor untuk tiap indikator konstruk. Menurut Hair dkk. (2014:101) pada kondisi tertentu nilai loading factor antara $0.4-0.7$ harus tetap dipertimbangkan untuk dipertahankan dengan memperhatikan kontribusinya terhadap validitas. Hasil pengujian pada tabel 1 menunjukkan bahwa semua butir pernyataan memenuhi unsur validitas convergent.

Tabel 1. Hasil Uji Convergent Validity

\begin{tabular}{cccc}
\hline No & Variabel/Indikator & Outer Loading & Keterangan \\
\hline SIMDA BMD & & \\
1 & SB_1 & 0.865 & Memenuhi convergent validity \\
2 & SB_2 & 0.706 & Memenuhi convergent validity \\
3 & SB_3 & 0.512 & Memenuhi convergent validity \\
4 & SB_4 & 0.521 & Memenuhi convergent validity \\
5 & SB_5 & 0.722 & Memenuhi convergent validity \\
6 & SB_6 & 0.692 & Memenuhi convergent validity \\
7 & SB_8 & 0.545 & Memenuhi convergent validity \\
\hline Laporan & Keuangan Pemerintah Daerah & & \\
1 & LK_1 & 0.764 & Memenuhi convergent validity \\
2 & LK_2 & 0.683 & Memenuhi convergent validity \\
3 & LK_3 & 0.627 & Memenuhi convergent validity \\
4 & LK_4 & 0.656 & Memenuhi convergent validity \\
5 & LK_5 & 0.811 & Memenuhi convergent validity \\
6 & LK_6 & 0.781 & Memenuhi convergent validity \\
7 & LK_9 & 0.562 & Memenuhi convergent validity \\
8 & LK_10 & 0.776 & Memenuhi convergent validity \\
9 & LK_11 & 0.781 & Memenuhi convergent validity \\
\hline Pencegahan Fraud Pengelolaan Barang Milik Daerah & & \\
1 & FR_2 & 0.531 & Memenuhi convergent validity \\
2 & FR_3 & 0.658 & Memenuhi convergent validity \\
3 & FR_5 & & \\
4 & FR_6 & 0.555 & Memenuhi convergent validity \\
5 & FR_7 & 0.515 & Memenuhi convergent validity \\
6 & FR_8 & 0.575 & Memenuhi convergent validity \\
7 & FR_9 & 0.502 & Memenuhi convergent validity \\
8 & FR_10 & 0.522 & Memenuhi convergent validity \\
& & 0.841 & Memenuhi convergent validity \\
\hline
\end{tabular}


Pengujian selanjutnya pada tahap evaluasi model pengukuran adalah pengujian discriminant validity. Hasil pengujian discriminant validity dapat dilihat pada nilai cross loading, kriteria yang disyaratkan adalah nilai dari cross loading untuk setiap variabel harus lebih besar dibandingkan dengan nilai korelasi terhadap indikator laten lainnya. Berdasarkan hasil pengujian ditemukan bahwa nilai cross loading dari masing-masing indikator penelitian lebih besar daripada nilai korelasi variabel laten.

Pada tahap evaluasi model pengukuran adalah pengujian discriminant validity. Hasil pengujian discriminant validity dapat dilihat pada nilai cross loading, kriteria yang disyaratkan adalah nilai dari cross loading untuk setiap variabel harus lebih besar dibandingkan dengan nilai korelasi terhadap indikator laten lainnya. Berdasarkan hasil pengujian ditemukan bahwa nilai cross loading dari masing-masing indikator penelitian lebih besar daripada nilai korelasi variabel laten.

Tahapan terakhir dari evaluasi model pengukuran adalah uji reliabilitas yang dilakukan dengan melihat nilai dari composite reliability. Berdasarkan hasil pengujian menunjukkan bahwa nilai composite reliability menunjukkan nilai yang lebih besar dari 0.7. Oleh karena itu, dapat disimpulkan bahwa seluruh variabel penelitian adalah reliabel. Hasil pengujian composite reliability dapat dilihat pada tabel 2.

Tabel 2. Hasil Uji Composite Reliability

\begin{tabular}{lcc}
\hline \multicolumn{1}{c}{ Variabel } & Composite Reliability & Keterangan \\
\hline Laporan Keuangan & 0.905 & Reliabel \\
Pencegahan Fraud & 0.811 & Reliabel \\
SIMDA BMD & 0.842 & Reliabel \\
\hline
\end{tabular}

Setelah melaksanakan evaluasi terhadap model pengukuran tahapan selanjutnya adalah evaluasi terhadap model struktural (inner model). Inner model dievaluasi dengan melihat besarnya presentase variance yang disajikan yaitu dengan melihat nilai R-Square untuk konstruk laten endogen, untuk melihat kekuatan prediksi dari model structural. Model structural dapat diklasifikasikan menjadi tiga yakni: $\geq 0.75$ merupakan model yang kuat $\geq 0.50$ sampai $\geq 0.75$ diklasifikasikan moderat dan $\leq 0.50$ adalah lemah. Berikut adalah hasil pengujian dari R-Square sebagaimana ditunjukkan pada tabel 3. Hasil pengujian R-square menunjukkan bahwa variabel laten eksogen yakni: SIMDA-BMD hanya dapat menjelaskan variabel endogen yaitu Laporan Keuangan Pemerintah Daerah dan pencegahan fraud pengelolaan barang milik daerah sebesar 6\% dan 5\%. Artinya, variabel endogen tersebut dipengaruhi oleh faktor-faktor lain. Kemampuan menjelaskan sebesar di bawah 50\% dalam klasifikasi R-square dikategorikan lemah.

Tabel 3. Hasil Pengujian R-Square $\left(\mathrm{R}^{2}\right)$

\begin{tabular}{ccc}
\hline Konstruk & $\boldsymbol{R}$-Square $\left(\boldsymbol{R}^{2}\right)$ & Keterangan \\
\hline LK & 0.062 & Lemah \\
FR & 0.052 & Lemah \\
\hline
\end{tabular}


Selanjutnya, test untuk menguji predictive relevance $\left(\mathrm{Q}^{2}\right)$. Nilai $\mathrm{Q}^{2}$ dapat diklasifikasikan menjadi 3 yakni model lemah, moderat dan kuat jika nilai $\mathrm{Q}^{2}$ adalah 0.02 , 0.15 dan 0.35. Berikut adalah nilai predictive relevance dilakukan melalui analisis blindfolding untuk mengetahui nilai crosvalidated communality sebagaimana ditunjukkan tabel 4 berikut ini.

Tabel 4. Hasil Analisis Blindfolding

\begin{tabular}{lccr}
\hline \multicolumn{1}{c}{ Konstruk } & SSO & SSE & Q $^{\mathbf{2}}$ (1-SSE/SSO) \\
\hline Laporan Keuangan & 648.000 & 414.333 & 0.361 \\
Pencegahan Fraud & 576.000 & 502.813 & 0.127 \\
SIMDA BMD & 504.000 & 387.486 & 0.231 \\
\hline
\end{tabular}

Berdasarkan hasil tabel 4 dapat diketahui bahwa nilai $\mathrm{Q}^{2}$ masing-masing variabel laten adalah lebih besar dari 0 (nol), sehingga dapat dijelaskan bahwa model penelitian ini memenuhi predictive relevance. Hal ini mengindikasikan bahwa data siap dilanjutkan ke tahap pengujian inner model selanjutnya yaitu pengujian hipotesis. Setelah melakukan evaluasi model struktural selanjutnya dilakukan pengujian terhadap model struktural melalui prosedur bootstrap. Nilai signifikansi yang digunakan (two-tailed) dengan t-value 1.96. Hasil evaluasi dan pengujian hipotesis model struktural disajikan pada tabel 5 sebagai berikut:

Tabel 5. Hasil Pengujian Hipotesis

\begin{tabular}{lccccc}
\hline $\begin{array}{c}\text { Hubungan } \\
\text { Variabel }\end{array}$ & Sample & Mean & STDEV & T Statistics & p Values \\
\hline SB -> LK & 0.248 & 0.258 & 0.254 & 0.975 & 0.330 \\
LK -> FR & 0.228 & 0.237 & 0.277 & 0.824 & 0.410 \\
SB -> FR & 0.057 & 0.081 & 0.105 & 0.537 & 0.592 \\
\hline
\end{tabular}

Pengujian inner model, evaluasi model dilakukan dengan mengevaluasi nilai signifikansi untuk mengetahui pengaruh variabel melalui prosedur bootstrapping. Hasil pengujian hipotesis diperoleh dengan cara membandingkan nilai dari t-statistik pada hasil bootstrapping dengan tingkat kepercayaan 95\% dibandingkan dengan nilai dari t-tabel. Untuk derajat kepercayaan 95\% nilai dari t-tabel adalah 1.96, oleh karena itu hipotesis penelitian akan diterima jika t-statistik $>1.96$. Selain itu, hasil pengujian hipotesis juga dapat dilihat dari nilai $\mathrm{p}$ value, dimana hipotesis dapat diterima jika nilai dari $\mathrm{p}$ value $<$ error atau tingkat kesalahan yang masih diperbolehkan yakni sebesar 5\%.

Hipotesis pertama menyatakan bahwa penggunaan SIMDA berpengaruh terhadap kualitas Laporan Keuangan Pemerintah Daerah. Artinya bahwa dengan menggunakan SIMDA unsur-unsur dalam karakteristik kualitatif laporan keuangan yang meliputi relevansi, keandalan, dapat dipahami dan dapat dibandingkan akan meningkat seiring dengan Pemerintah Daerah semakin baik dalam penerapan SIMDA BMD dalam penyusunan laporan keuangan. Hasil pengujian menunjukkan bahwa nilai dari t-statistik SIMDA BMD terhadap Laporan Keuangan adalah 0.975 dengan nilai $p$ value 0,365 dengan arah koefisien regresi positif. Hasil pengujian hipotesis ini menjelaskan bahwa efektivitas penggunaan SIMDA berpengaruh positif namun tidak signifikan terhadap kualitas Laporan Keuangan Pemerintah Daerah. Oleh karena itu, dapat hipotesis pertama 
dalam penelitian ini ditolak. Namun demikian arah koefisien positif antara penggunaan SIMDA dengan kualitas Laporan Keuangan mengindikasikan terdapat keterkaitan antara peningkatan terhadap kualitas penggunaan SIMDA dengan peningkatan kualitas laporan keuangan yang dihasilkan. Akan tetapi pengaruh yang diberikan oleh SIMDA terhadap peningkatan kualitas laporan keuangan tersebut tidak signifikan.

Beberapa alasan argumentatif dapat menjadi indikasi tidak signifikannya pengaruh penggunaan SIMDA terhadap kualitas laporan keuangan. Pertama, pengaruh dari lemahnya nilai $\mathrm{R}$ square yang berada hanya pada tingkat $6 \%$ artinya masih banyak faktorfaktor lain yang turut juga menjadi prediktor untuk meningkatkan kualitas laporan keuangan selain dari SIMDA BMD yang belum dispesifikasikan dalam model penelitian. Kedua, dalam aspek praktis bahwa SIMDA BMD secara faktual dapat mempercepat proses penyelesaian Laporan Keuangan Pemerintah Derah (LKPD) karena memiliki fitur-fitur yang komprehensif dari mulai pencatatan sampai dengan pelaporan. Namun, yang menjadi kendala utama dalam penyusunan laporan keuangan pemerintah daerah yang terkait langsung dengan unsur-unsur dalam karakteristik kualitatif laporan keuangan adalah masalah relevansi dan keandalan data. Relevansi menjadi masalah yang tidak dapat diselesaikan oleh SIMDA BMD manakala Organisasi Perangkat Daerah (OPD) tidak melakukan input data dalam tenggat waktu pelaporan yang telah ditentukan. Sementara itu, terkait dengan keandalan SIMDA tidak memiliki data pembanding selain dari data yang akan diinput oleh user SIMDA. Oleh karena itu, sisi inputan menjadi bagian yang tidak dapat tercover oleh SIMDA dari sisi keandalan, pengguna SIMDA lah yang harus mampu memilah data inputan yang memiliki keandalan. Alasan lainnya, dari sisi proses dan output SIMDA BMD memiliki tingkat keandalan yang tinggi karena olahan data yang disajikan akan diproses sesuai dengan ketentuan peraturan perundang-undangan.

Hipotesis kedua yang menyatakan bahwa kualitas laporan keuangan pemerintah daerah berpengaruh terhadap pencegahan fraud Pengelolaan Barang Milik Daerah mengindikasikan bahwa dengan meningkatnya kualitas laporan keuangan melalui unsur karakteristik kualitatif laporan keuangan maka akan efektif untuk meningkatkan pencegahan fraud pengelolaan barang milik daerah. Hasil pengujian menunjukkan bahwa nilai dari t-statistik laporan keuangan terhadap pencegahan fraud pengelolaan barang milik daerah (BMD) adalah 0.824 dengan nilai $p$ value 0,410 . Hasil pengujian hipotesis ini tidak memenuhi kriteria yang nilai t-statistik yang dipersyaratkan $>1,96$ atau nilai $p$ value $<0,05$. Dengan demikian hipotesis kedua dalam penelitian ini ditolak. Namun demikian, arah hubungan antara kualitas laporan keuangan dan pencegahan fraud pengelolaan barang milik daerah adalah positif dengan nilai koefisien parameter sebesar 0.228. Artinya bahwa, pengaruh yang diberikan oleh laporan keuangan terhadap pencegahan fraud pengelolaan barang milik daerah ada namun, tidak secara signifikan mempengaruhi kuat atau lemahnya pencegahan fraud. Temuan ini dapat dijelaskan dalam beberapa argumentasi. Salah satu dari bentuk fraud adalah salah saji laporan keuangan yang disengaja (fraudulent financial statement) yang merupakan aksi oleh manajer atau aparatur untuk menyajikan laporan keuangan yang tidak sesuai dengan keadaan yang sebenarnya. Kondisi ini tentu tidak dapat dideteksi melalui penyusun laporan, karena justru yang bermasalah adalah laporan keuangan itu sendiri. Oleh karena itu, diperlukan tindakan baik melalui kegiatan pengendalian yang efektif maupun melalui proses audit agar tindakan fraud tersebut dapat 
terungkap. Hal ini sejalan dengan apa yang dikemukakan oleh Albercht (2014) bahwa tindakan fraud tidak dapat dideteksi melalui laporan keuangan, karena pelaku fraud cenderung untuk menutupi tindakannya. Selain itu, bentuk pencegahan fraud pada pengelolaan barang milik daerah lebih kepada pengaman aset yang dimiliki oleh pemerintah daerah melalui penyimpanan dokumen kepemilikan dan inventarisasi barang milik daerah. Hasil inventarisasi inilah yang nantinya dilaporkan dalam Laporan Keuangan Pemerintah Daerah (LKPD) sebagai bentuk penambahan atau pengurangan aset yang dimiliki oleh organisasi pemerintah daerah. Dengan demikian hubungan antara laporan keuangan dan pencegahan fraud tidak terpaut secara langsung.

Hipotesis ketiga menyatakan bahwa penggunaan SIMDA BMD berpengaruh terhadap pencegahan fraud Pengelolaan Barang Milik Daerah. Artinya semakin baik sistem informasi yang dimiliki oleh Pemerintah Daerah akan berdampak terhadap pencegahan fraud pengelolaan barang milik daerah. Hasil Pengujian terhadap hipotesis ketiga menghasilkan nilai t-statistik 0.537 dengan nilai $p$ value 0.592 . Hasil ini tidak memenuhi kriteria yang ditetapkan, oleh karena itu hipotesis yang ketiga ini ditolak. Walaupun demikian, arah hubungan pengujian variabel eksogen ini masih sejalan dengan teori dan penelitian terdahulu. Hal ini ditunjukkan dengan nilai koefisien parameter 0.057 artinya bahwa pengaruh yang diberikan oleh SIMDA BMD terhadap pencegahan fraud ada, namun tidak signifikan mempengaruhi kuat atau lemahnya pencegahan fraud pengelolaan barang milik daerah. Temuan penelitian yang tidak signifikan ini dapat diargumentasikan bahwa mekanisme pencegahan fraud melalui sistem informasi diperoleh melalui transparansi proses dan keamanan data yang dimiliki oleh organisasi. Penggunaan SIMDA BMD akan membuat seluruh proses pengadaan organisasi akan terdokumentasi dengan baik sehingga evaluasi atau pengawasan dapat dilakukan oleh setiap aparatur. Dengan demikian, risiko kehilangan aset dari proses pengadaan dapat terpantau. Begitu juga dengan keamanan basis data, penggunaan SIMDA BMD menyimpan data-data terkait barang inventaris yang dimiliki oleh organisasi perangkat daerah sampai dengan distribusi barang tersebut ke setiap ruangan yang ada. Belum optimalnya peran SIMDA BMD dalam pencegahan fraud pengelolaan barang milik daerah sebagaimana hasil pengujian hipotesis dapat dikonfirmasi dengan jawaban dari mayoritas sampel penelitian terhadap pernyataan pada indikator fleksibilitas sistem. Penggunaan SIMDA BMD memang masih memiliki keterbatasan akses, dimana penggunaan SIMDA hanya dapat dilakukan di Badan Pengelolaan Keuangan dan Aset Daerah (BPKAD) saja selaku pembantu pengelola barang milik daerah. Hal inilah yang menyebabkan minimnya frekuensi penggunaan SIMDA oleh aparatur yang berdampak juga terhadap peran SIMDA dalam pencegahan fraud. Dengan demikian demikian hasil penelitian ini tidak memberikan bukti yang sejalan dengan hasil penelitian sebelumnya seperti Al-Hiyari et al. (2013), Rapina (2014) serta Fitriati dan Mulyani (2015) tentang efektivitas SIMDA dalam meningkatkan secara signifikan kualitas laporan keuangan dan pencegahan fraud dalam pencegahan fraud pengelolaan barang milik daerah. 


\section{Kesimpulan, Implikasi dan Keterbatasan}

Hasil penelitian menunjukkan bahwa penggunaan SIMDA tidak berpengaruh terhadap peningkatan kualitas laporan keuangan dan pencegahan fraud pengelolaan barang milik daerah. Temuan lain penelitian ini juga menyatakan bahwa kualitas laporan keuangan juga tidak berpengaruh terhadap pencegahan fraud pengelolaan barang milik daerah. Hasil penelitian ini mengindikasikan bahwa efektivitas pemanfaatan SIMDA dalam menghasilkan laporan keuangan yang berkualitas masih perlu ditingkatkan lebih optimal lagi sehingga dapat menyajikan informasi keuangan yang andal dan relevan untuk pengambilan keputusan. SIMDA memungkinkan transparansi proses dan keamanan data keuangan dan aset daerah yang dimiliki oleh organisasi pemerintahan daerah sehingga perlu ditingkatkan lagi efektivitas pemanfaatannya sehingga seluruh proses pengelolaan dan pengadaan organisasi akan terdokumentasi dengan baik sehingga evaluasi atau pengawasan dapat dilakukan oleh setiap aparatur.

Penelitian ini memiliki beberapa keterbatasan pertama lemahnya koefisien determinasi $\left(\mathrm{R}^{2}\right)$ akibat dari analisis yang hanya menggunakan SIMDA sebagai variabel eksogen, oleh karena itu diharapkan untuk peneliti selanjutnya agar dapat mengobservasi kualitas laporan keuangan dan pencegahan fraud menggunakan variabel penjelas lainnya seperti tingkat ketepatwaktuan dalam pelaporan, dan sistem pengendalian internal. Penelitian lainnya dapat mengeksplorasi prediktor kesuksesan implementasi SIMDA sesuai dengan faktor kontekstual organisasi seperti komitmen manajemen, kualitas data dan sistem informasi.

\section{Referensi}

Albrecht, W. S., K. R. Howe, dan M. B. Romney. 1984. Deterring Fraud: The Internal Auditor's Perspective.Altomonte Springs, FL: The Institute of Internal Auditors' Research Foundation.

Alfian, Muhammad. 2015. Faktor Pendukung Implementasi SIMDA dan Pengaruhnya terhadap Kualitas Laporan Keuangan terhadap pada SKPD Kabupaten Kulon Progo. Jurnal Ekonomi dan Bisnis, 18 (3), 119-131.

Al-Hiyari, Ahmad, Mohammed Hammod Al-Masregy, Nik Kamariah Nik Mat, \& Jamal Mohammedesmailalekam.2013. Factors that Affect Accounting Information Sistem Implementation and Accounting Information Quality: A Survey in University Utara Malaysia. American Journal of Economic, 3 (1), 27-31.

Al-Zwyalif, Inaam. 2015. The Role of Internal Control In Enhancing Corporate Governance: Evidance From Jordan. International Journal Business and Management, 10 (7), 57-66

Bologne, J. 1993. Handbook on corporate fraud: Prevention, detection, and investigation: Butterworth-Heinemann

BPKP. 2017. Substansi \& Sistem Requirments SIMDA BMD Versi 2.0.7. Deputi Pengawasan Bidang Penyelenggaran Keuangan Daerah. Jakarta. 
BPKP.2008. Fraud Auditing. Pusat Pendidikan dan Pelatihan Pengawasan Badan Pengawasan Keuangan dan Pembangunan. Jakarta.

Cressey, D. R. 1950. The Criminal Violation of Financial Trust. American Sociological Review, 15 (6): 738-743.

Dorminey J., A. S. Fleming., M. J. Kranacher dan R. A. Riley, Jr. 2012. The Evolution of Fraud Theory. Issues in Accounting Education 27 (2): 555-579.

Fahrurrozi, Handia, Akram, dan Prayitno Basuki. 2019. Pengaruh Kualitas Aparatur Melalui SIMDA dan Sistem Pengendalian Internal Terhadap Pencegahan Fraud Pengelolaan BMD. E-Jurnal Akuntansi Universitas Udayana, 27 (1), 675-707.

Fitriani, Azmi and Sri Mulyani. 2015. Faktors That Affect Accounting Information System Success and Its Implication on Accounting Information Quality. Asian Journal of Information Technology, 14 (5), $154-161$.

Ghozali, Imam dan Hengky Latan.2015. Partial Least Squares Konsep, Teknik dan Aplikasi Menggunakan Program SmartPLS 3.0. Semarang. Badan Penerbit Universitas Diponegoro

Hair, J.F, G. Thomas M.H, Christian M.R, and Marko S.2014. A Primer Partial Least Squares Structural Equation Modeling (PLS-SEM). SAGE Publications, Inc. California

http://www.bpkp.go.id/sakd/konten/333/Pengenalan-Sistem-Informasi-ManajemenDaerah-SIMDA-.bpkp diaskses pada 6 September 2019

https://www.merriam-webster.com/dictionary/fraud diakses pada 19 September 2019

Laksono, Hari. 2017. Evaluasi Kesuksesan SIMDA BMD Pada Pemerintah Kabupaten Grobogan Menggunakan Model Kombinasi Delone McLean dan Technology Acceptance Model. Jurnal Tata Kelola dan Akuntabilitas Keuangan Negara, 3 (2), 151-167

Maksum, Umar., Zaki baridwan \& Imam Subekti. 2017. The Determinant of Acceptance of SIMDA (Information System of District Management) Implementation on the Government of Batu City. Journal of Accounting and Business Education, 1 (2), 298-320

Peraturan Menteri Dalam Negeri Nomor 19 Tahun 2016. Pedoman Pengelolaan Barang Milik Daerah. Jakarta

Peraturan Pemerintah Nomor 08 Tahun 2006. Pelaporan Keuangan dan Kinerja Instansi Pemerintah. Jakarta.

Peraturan Pemerintah Nomor 56 Tahun 2005. Sistem Informasi Akuntasi Keuangan Daerah. Jakarta.

Peraturan Pemerintah Nomor 71 Tahun 2010. Standar Akuntansi Pemeritah. Jakarta. 
Pulungan, M. Soleh. 2014. Optimalisasi SIMDA dalam Mewujudkan Pengelolaan Keuangan Daerah Kabupaten Kutai Kartanegara Provinsi Kalimantar Timur Yang Lebih Berkualitas. Jurnal Bina Praja, 6 (4): 269-282

Puspasari, Novita.2016. Fraud Theory Evolution and Its Relevance to Fraud Prevention in The Village Government in Indonesia. Asia Pasific Fraud Journal, 1 (2): 177-188.

Rapina. 2014.Faktors Influencing the Quality of Accounting Information Sistem and Its Implications on The Quality of Accounting Information. Research Journal of Financial and Accounting, 5 (2), 148-154

Sugiyono, 2014. Metode Penelitian Bisnis. Bandung. Alfabeta

Supriyanto. 2015. Analisis Implementasi Sistem Informasi Manajemen Daerah (SIMDA) Barang Milik Daerah. Universitas Sebelas Maret. Tidak Dipublikasikan.

Warsito. Dwijo 2014. Manajemen Pemerintah Daerah. Jakarta. Pusdiklat BPKP 